\title{
Growth Factor Activation of the Estrogen Receptor in Vascular Cells Occurs via a Mitogen-activated Protein Kinase-independent Pathway
}

\author{
Richard H. Karas, Elizabeth Ann Gauer, Hallie E. Bieber, Wendy E. Baur, and Michael E. Mendelsohn \\ Molecular Cardiology Research Center, Tupper Research Institute, New England Medical Center/Tufts University School of Medicine, \\ Boston, Massachusetts 02111
}

\begin{abstract}
The classical estrogen receptor $\mathrm{ER} \alpha$ mediates many of the known cardiovascular effects of estrogen and is expressed in male and female vascular cells. Estrogen-independent activation of $E R \alpha$ is known to occur in cells from reproductive tissues, but has not been investigated previously in vascular cells. In this study, transient transfection assays in human saphenous vein smooth muscle cells (HSVSMC) and pulmonary vein endothelial cells (PVEC) demonstrated ER $\alpha$ dependent activation of estrogen response element-based, and vascular endothelial growth factor-based reporter plasmids by both estrogen-deficient FBS (ED-FBS) and EGF. In nonvascular cells, ER $\alpha$-mediated gene expression can be activated via mitogen-activated protein (MAP) kinaseinduced phosphorylation of serine 118 of ER $\alpha$. However, in vascular cells, we found that pharmacologic inhibition of MAP kinase did not alter EGF-mediated ER $\alpha$ activation. In addition, a mutant ER containing an alanine-for-serine substitution at position 118 was activated to the same degree as the wild-type receptor by ED-FBS and EGF in both HSVSMC and PVEC. Furthermore, constitutively active MAP kinase kinase (MAPKK) activated ER $\alpha$ in $\operatorname{Cos} 1$ cells as expected, but MAPKK inhibited ER activation in PVEC. We conclude that growth factors also stimulate $\mathrm{ER} \alpha$-mediated gene expression in vascular cells, but find that this occurs via a MAP kinase-independent pathway distinct from that reported previously in nonvascular cells. (J. Clin. Invest. 1998. 101:2851-2861.) Key words: steroid hormone receptors - gene transcription - crosstalk - vascular smooth muscle cells • vascular endothelial cells
\end{abstract}

\section{Introduction}

Estrogen deficiency is associated with increased risk of developing coronary artery disease (1); estrogen replacement therapy attenuates this risk in postmenopausal women (2-4). While these atheroprotective effects of estrogen are mediated in part by effects of estrogens on systemic factors (5-7), the

Address correspondence to Richard H. Karas, M.D., Ph.D., Molecular Cardiology Research Center, New England Medical Center, 750 Washington Street, \#80, Boston, MA 02111. Phone: 617-636-8776; FAX: 617-636-1444; E-mail: richard.karas@es.nemc.org

Received for publication 5 August 1997 and accepted in revised form 1 April 1998.

J. Clin. Invest.

(C) The American Society for Clinical Investigation, Inc. 0021-9738/98/06/2851/11 \$2.00

Volume 101, Number 12, June 1998, 2851-2861

http://www.jci.org majority of the vasculoprotective effects of estrogen appear to be due to direct effects of estrogens on vascular cells $(4,8)$. Direct effects of estrogens on vascular cells have been demonstrated in vitro and in vivo in both animal and human models (8-20), including effects on gene expression $(17,18)$, ion channel function $(12,19,20)$, elaboration of and response to vasoactive substances $(10,13-16,21,22)$, as well as vascular smooth muscle cell (VSMC) ${ }^{1}$ proliferation and migration (22-25), and endothelial cell (EC) proliferation (26). Estrogen receptor $\alpha$ $(\mathrm{ER} \alpha)$ is expressed in human $\operatorname{VSMC}(27,28)$, and we have shown that the VSMC ER is capable of altering gene expression in these cells $(17,28)$. ER $\alpha$ expression has also been demonstrated recently in human EC (29-32). The effects of estrogens on gene expression and proliferation in vascular cells are likely mediated by vascular estrogen receptors, but some of the rapid, direct effects of estrogen on vascular cells may be mediated by pathways independent of these receptors, or by estrogen receptors acting through novel, nontranscriptional pathways (10-12, 14, 15, 20, 32, 33).

$\mathrm{ER} \alpha$ is expressed in VSMC derived from both women and men (28). Despite the low circulating levels of estrogen found in men, a physiologic role for ER $\alpha$ in males is supported by both animal and human studies. For example, estrogen administration improves vascular reactivity in some men (34-36), inhibits the response to carotid injury in castrated male rats (37), and reduces plaque formation in transgenic male mice which express high levels of apoE (38). Furthermore, disruption of the $\mathrm{ER} \alpha$ gene leads to an abnormal phenotype in male mice that includes both abnormal behavior and sterility (39-42). Recent reports have also described abnormal vascular reactivity and skeletal maturation in an adult human male harboring a homozygous truncation mutation in the $\mathrm{ER} \alpha$ gene $(43,44)$. At present, however, the mechanism(s) by which ER $\alpha$ mediates its vascular effects in the presence of low levels of estrogen is unclear.

Estrogen receptors, members of the large family of steroid hormone receptors that act as ligand-activated transcription factors $(45,46)$, activate gene expression via $\mathrm{NH}_{2}$-terminal and/or COOH-terminal transactivation domains (AF-1 and AF-2, respectively). In nonvascular cells, alternative, hormone-independent mechanisms for receptor activation also exist. In various tumor cells, $\mathrm{ER} \alpha$-dependent transcriptional transactivation of an estrogen-response element (ERE) in the absence of estrogen has been described in response to dopaminergic stimulation, elevation of cAMP, and by specific cy-

1. Abbreviations used in this paper: EC, endothelial cell; ECL, enhanced chemiluminescence; ED-FBS, estrogen-deficient FBS; ER, estrogen receptor; ERE, estrogen-response element; HSVSMC, human saphenous vein smooth muscle cells; MAP, mitogen-activated protein; MAPK, MAP kinase; MAPKK, MAPK kinase; PVEC, pulmonary vein endothelial cells; SFM, serum-free media; VEGF, vascular endothelial growth factor; VSMC, vascular smooth muscle cell. 
clins (47-50). EGF has also been shown to activate $\mathrm{ER} \alpha$ in uterine and ovarian adenocarcinoma cells (51-53). In Cos1 and $\mathrm{HeLa}$ cells, the mechanism for this ligand-independent ER activation pathway involves mitogen-activated protein (MAP) kinase-dependent phosphorylation of serine 118 of $\mathrm{AF}-1$ in $\mathrm{ER} \alpha(54,55)$. However, hormone-independent activation of $\mathrm{ER} \alpha$ has not been studied yet in vascular cells. In this study, we demonstrate that $\mathrm{ER} \alpha$ also can be transcriptionally activated in vascular cells in an estrogen-independent manner, but show that hormone-independent activation of $\mathrm{ER} \alpha$ in vascular cells occurs by a MAP kinase-independent pathway.

\section{Methods}

\section{Cell culture techniques}

Human saphenous vein smooth muscle cells (HSVSMC) were cultured from explants derived from surgical specimens as described (28). Cos 1 cells and HeLa cells were obtained from American Type Culture Collection (Rockville, MD) and maintained in DME with $10 \%$ FBS. Rat pulmonary vein endothelial cells (PVEC), the kind gift of Paul Hassoun (New England Medical Center, Boston, MA), were maintained in RPMI. For all experiments, phenol red-free media was used. Unless otherwise noted, serum stimulation was achieved as previously described (28), by application of defined estrogen-deficient FBS (ED-FBS; Hyclone, Logan, UT) in which the estrogen content was $<2.6 \times 10^{-11} \mathrm{M}$. In a subset of experiments, charcoal-stripped ED-FBS was prepared by adding PBS-rinsed Dextran-70 (Sigma Chemical Co., St. Louis, MO) and charcoal at a 1:100 (wt/vol) and 1:10 (wt/vol) dilution, respectively. The mixture was incubated at $55^{\circ} \mathrm{C}$ for $1 \mathrm{~h}$, centrifuged, and subjected to filter sterilization. In preliminary experiments to determine the adequacy of hormone removal, $1 \mathrm{nM}$ $\left[{ }^{3} \mathrm{H}\right] 17 \beta$-estradiol was added to FBS before stripping and the residual radioactivity was determined after the stripping protocol. This process demonstrated removal of $98-99.6 \%$ of the $17 \beta$-estradiol in three independent experiments.

\section{Transfection assays}

All transfections were carried out by electroporation as described (28). In experiments designed to investigate the direct effects of EDFBS stimulation, cells were growth arrested by serum starvation for 72-96 h before transfection. VSMC, Cos 1 cells, and HeLa cells were arrested in DME supplemented with $0.5 \mu \mathrm{M}$ insulin, $0.5 \mu \mathrm{g} / \mathrm{ml}$ transferrin, $0.2 \mathrm{mM}$ ascorbate (56), and $10^{-8} \mathrm{M}$ ICI 182780. PVEC were similarly serum-deprived in RPMI. Cellular viability was assessed extensively by trypan blue exclusion during serum deprivation in pilot studies before initiation of the studies shown.

\section{Plasmids}

The reporter plasmids ERE- $L u c$, containing three copies of the Xenopus vitellogenin ERE proximal to the thymidine kinase promoterdriving expression of the luciferase cDNA, and TK- $L u c$, identical to ERE- $L u c$ but lacking the ERE, were the kind gift of C. Glass (University of California at San Diego, La Jolla, CA) (57). The reporter plasmids mVEGF- $L u c$, containing $1.6 \mathrm{~kb}$ of the $5^{\prime}$ portion of the murine vascular endothelial growth factor (VEGF) gene (including 1.2 $\mathrm{kb}$ of $5^{\prime}$-flanking region) driving expression of the luciferase gene, and $\Delta$ Sma/VEGF- $L u c$, similar to mVEGF- Luc but lacking the entire 5 '-flanking region) were the kind gift of P. D'Amore (Children's Hospital Medical Center, Boston, MA). The expression plasmid $\mathrm{pCMV}_{3^{-}}$ ER was constructed by cloning the full-length human ER cDNA into the CMV-driven plasmid pCDNA3.1 (Invitrogen, San Diego, CA). The plasmid $\mathrm{pCMV}_{3}$-ER-NTF was produced by inserting the coding sequence for an eight-amino acid epitope tag recognized by a commercially available mAb, M2 (Eastman Kodak, Rochester, NY) at the $5^{\prime}$ end of the $\mathrm{ER} \alpha$ coding sequence in $\mathrm{pCMV}_{3}$-ER. The expression plasmid $\mathrm{pCMV}_{3}$-ER-s118a was constructed by mutating serine 118 to alanine by the method of Kunkel et al. (58) and the mutation was confirmed by sequencing in both directions. The expression plasmid $\mathrm{pCMV}_{3}$-ER-271 was constructed by digestion of $\mathrm{pCMV}_{3}$-ER with $\mathrm{Xcm} 1$ and $\mathrm{Xho1}$ to remove the coding sequence distal to amino acid 271 in the D region of the receptor, followed by blunt-ending of the construct with a polymerase reaction and religation. Truncated protein of the predicted size was expressed by $\mathrm{pCMV}_{3}$-ER-271, as demonstrated by Western blotting (data not shown). The expression plasmid SR $\alpha 456-\mathrm{HA}$, driving expression of a constitutively activated form of MAP kinase (MAPK) kinase, was the kind gift of Y. Gotoh (59).

After transfection, cells were plated for $4 \mathrm{~h}$ in ED-FBS-containing medium to allow for cell attachment, then rinsed three times with serum-free medium, and finally placed into experimental media. In addition to ED-FBS, cells were grown in the presence or absence of the specific ER antagonist ICI 182780 (kind gift of A. Wakeling, Zeneca Pharmaceuticals, Cheshire, England), $100 \mathrm{ng} / \mathrm{ml}$ EGF (CalBiochem, La Jolla, CA), PDGF (AB isoform at $10 \mathrm{nM}$; Sigma Chemical Co.), tamoxifen (Sigma Chemical Co.), the MAP kinase kinase (MAPKK) inhibitor PD 98059 (see ref. 60; New England Biolabs, Bedford, MA) or 17 $\beta$-estradiol (E2; Sigma Chemical Co.) as described in Results. Steroid compounds were dissolved in ethanol, which was applied in appropriate concentrations to control wells to ensure a constant concentration of vehicle $(<0.02 \%)$ in all cases. Cells were harvested for determination of luciferase activity (as described in ref. 28) 48-72 h after transfection. All luciferase results presented were normalized to the activity of a cotransfected $\beta$-galactosidase expression plasmid (pCMV-LacZ), according to the manufacturer's guidelines (Galactolite; Tropix, Bedford, MA).

\section{Immunoblotting}

$E R$. Cells were transfected with the expression plasmid $\mathrm{pCMV}_{3}$-ERNTF with or without the SR $\alpha 456-\mathrm{HA}$ expression plasmid. Cells were plated in 100-mm dishes, exposed to experimental conditions for $48 \mathrm{~h}$, and lysed as described (61) with lysis buffer modified to include $0.6 \mathrm{M}$ $\mathrm{NaCl}$ and $10 \mathrm{mM} \mathrm{Na}$ molybdate. Equal volumes of total cellular protein were separated by SDS-PAGE and transferred to nitrocellulose. Immunoblotting was performed either with the M2 antibody or in some experiments with an antibody against the double-phosphorylated form of MAPK (Promega Biotec, Madison, WI). Immunoblots were washed and then incubated with an anti-mouse-HRP secondary antibody and developed by standard enhanced chemiluminescence (ECL) techniques. To confirm equal protein loading between lanes, membranes were stripped and reprobed with monoclonal antismooth muscle action antibody (Sigma Chemical Co.).

$M A P K$. PVEC plated in six-well plates were made quiescent by overnight serum deprivation and then incubated for $1 \mathrm{~h}$ in the absence or presence of the MAPKK inhibitor PD98059. The cells were then treated with vehicle or $100 \mathrm{ng} / \mathrm{ml}$ EGF for $15 \mathrm{~min}$. The cells were lysed as described above, and equal volumes of total cellular protein were separated by SDS-PAGE, transferred to nitrocellulose and immunoblotted with a mouse $\mathrm{mAb}$ against the active form of MAPK (Promega Biotec). After development by standard ECL techniques, the membrane was stripped and confirmed to be blank by repeat ECL development. The membrane was then reprobed with an antiMAPK antibody (Upstate Biotechnology, Inc., Lake Placid, NY) and finally developed with ECL.

\section{Proliferation assays}

HSVSMC were plated in 96-well plates at a density of $\sim 2,000$ cells/ $\mathrm{cm}^{2}$ and rendered quiescent by serum deprivation as described above. $1 \mu \mathrm{Ci}\left[{ }^{3} \mathrm{H}\right]$ thymidine was then added to each well and the cells were maintained in the presence or absence of $100 \mathrm{ng} / \mathrm{ml}$ EGF or $10 \mathrm{nM}$ PDGF for $24 \mathrm{~h}$. The cells were then rinsed three times with PBS, lysed with $1 \mathrm{~N} \mathrm{HCl}$, and neutralized with $\mathrm{NaHCO}_{3}$. Incorporated $\left[{ }^{3} \mathrm{H}\right]$ thymidine was quantified by scintillation counting.

\section{Statistical analysis}

All data are presented as mean \pm SEM. Two-way comparisons were made with the Student's $t$ test; multiple group comparisons were 


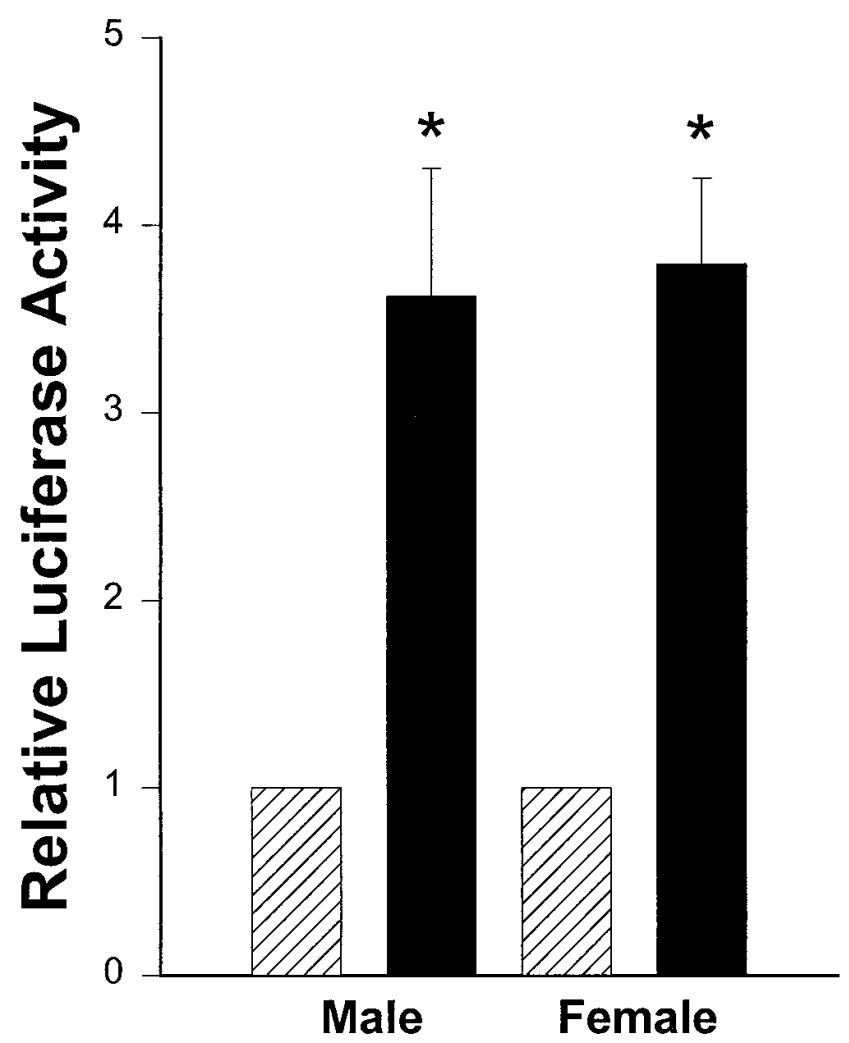

Figure 1. Estrogen-deficient serum stimulation activates an ERE in VSMC derived from males and females. Quiescent VSMC derived from saphenous veins of male or female patients were transiently transfected with an ERE-Luc plasmid and grown for $48 \mathrm{~h}$ in SFM (hatched bars) or in the presence of 10\% ED-FBS (solid bars). In both cell types, ED-FBS treatment increased the activity of the EREcontaining reporter plasmid. Bars, mean ( \pm SEM) of luciferase activity relative to the activity in quiescent cells. ${ }^{*} P<0.01$ vs. SFM.

made by ANOVA. A value of $P \leq 0.05$ was considered statistically significant.

\section{Results}

Stimulation of VSMC with ED-FBS results in activation of an ERE reporter plasmid. VSMC derived from saphenous veins of men or women were growth arrested by serum starvation and then transfected with either ERE-Luc or a control reporter plasmid lacking the ERE sequences (TK-Luc). In the absence of estrogen, 48-h stimulation of male-derived HSVSMC with ED-FBS resulted in a 3.6 \pm 0.7 -fold increase in activity of the ERE- $L u c$ reporter plasmid (Fig. $1 ; n=9 ; P<$ 0.01). Similar results were obtained using HSVSMC derived from women $(3.8 \pm 0.5$-fold, $n=6, P<0.01)$. ED-FBS had no effect on the activity of the control vector TK-Luc (data not shown). Independent experiments in which VSMC were stimulated with charcoal-stripped FBS yielded similar results (data not shown).

$E D-F B S$-induced activation of the ERE is mediated by ERQ via AF-1. To examine the role of ER in ED-FBS-induced activation of the ERE- $L u c$ reporter, we investigated the effects of overexpression of ER $\alpha$ in HSVSMC on ED-FBS-mediated transactivation. As shown in Fig. $2 A$, transient transfection of HSVSMC with the expression plasmid $\mathrm{pCMV}_{3}$-ER increased activation of ERE by ED-FBS from $3.8 \pm 0.7$-fold to $15.3 \pm 4.4$ fold $(n=27 ; P<0.05)$. Co-incubation of HSVSMC with the specific estrogen receptor antagonist ICI 182780 inhibited EDFBS-mediated activation in a dose-dependent fashion in the absence (data not shown) or presence (Fig. $2 A$ ) of ER $\alpha$ overexpression $(P<0.05)$. Estrogen alone led to the expected activation of the ER in these studies (5.8 \pm 1 .1-fold; $n=20 ; P<$ $0.05)$.

We also examined the effects of transfection of ER $\alpha$ on ED-FBS stimulation of the ERE in a second type of vascular cell, PVEC. Based on both Western blotting and transient transfection experiments, PVEC are devoid of functional ER (data not shown). In PVEC, ED-FBS treatment had no effect on ERE activation (Fig. $2 \mathrm{~B}$ ). However, ED-FBS treatment of PVEC cotransfected with $\mathrm{pCMV}_{3}$-ER resulted in a 6.6 $\pm 0.9-$ fold increase in ERE activation (Fig. $2 B ; n=27 ; P<0.001$ ), an effect that again was completely inhibited by ICI 182780 . The observed increase in ERE activation upon FBS treatment did not result from alterations in $\mathrm{ER} \alpha$ protein levels, which were unchanged after FBS treatment (inset, Fig. $2 \mathrm{~B}$ ), and estrogen alone again gave the expected activation of the ER in PVEC (3.1 \pm 0.4 -fold; $n=16 ; P<0.01)$. Similar results to those of Fig. $2 \mathrm{~B}$ also were observed in HeLa cells (3.6 \pm 0.3 -fold activation; $n=18 ; P<0.01 \mathrm{ED}-\mathrm{FBS}$ vs. serum-free media [SFM], data not shown).

To begin to define which domains within $\mathrm{ER} \alpha$ mediate ED-FBS transactivation of the ERE, we examined the activity of an ER truncated at amino acid 271. ER271 contains the DNA binding domain and AF-1, but lacks the hormone-binding domain and AF-2. As shown previously, ED-FBS had no effect on untransfected PVEC, but caused a 5.9 \pm 1.2 -fold increase in luciferase activity in PVEC transfected with wildtype ER $(n=12 ; P<0.01$; Fig. $2 C)$ and a $3.1 \pm 0.3$-fold increase in PVEC transfected with ER-271 $(n=12 ; P<0.01)$. ER-271 was not activated by E2, consistent with the absence of the hormone-binding domain in this construct (Fig. $2 \mathrm{C}$ ). These data demonstrate that AF-1 in ER $\alpha$ can mediate ED-FBS-induced transactivation of the ERE-Luc reporter.

ER-mediated transcriptional transactivation of a VEGF reporter. To examine whether E2-independent activation of the ER can activate transcription of a physiologically relevant gene, we examined the effect of ED-FBS on mVEGF-Luc gene expression. In human VSMC, ED-FBS treatment resulted in an 11.2 \pm 4.0 -fold activation of the VEGF reporter plasmid ( $n=6 ; P<0.05$; Fig. $3 A$ ). This activation was markedly inhibited by treatment with the ER antagonist ICI 182780, an effect partially reversed in a dose-dependent manner by co-incubation with E2 (Fig. $3 A$ ). ED-FBS had no effect on the control plasmid $\Delta \mathrm{Sma} / \mathrm{VEGF}-L u c$, which lacks the $5^{\prime}$ flanking sequence of the VEGF gene (data not shown). These effects of ED-FBS stimulation on mVEGF- $L u c$ were also studied in HeLa cells (an ER null cell [62]) without and with coexpression of $\mathrm{ER} \alpha$. In the absence of $\mathrm{ER} \alpha$ coexpression, ED-FBS treatment had no significant effect on VEGF reporter activity in $\mathrm{HeLa}$ cells (Fig. $3 \mathrm{~B}$, first two bars). In the presence of cotransfected ER $\alpha$, however, ED-FBS treatment resulted in a $2.9 \pm 0.4$-fold activation of VEGF expression $(n=24 ; P<0.05)$. As in HSVSMC, this activation also was blocked by ICI 182780 , and the inhibition of ICI 182780 could be reversed by co-incubation with E2 (Fig. $3 \mathrm{~B}$ ). Hormone treatment had no effect in HeLa cells on the control vector $\Delta$ Sma/VEGF-Luc (data not shown). 
A
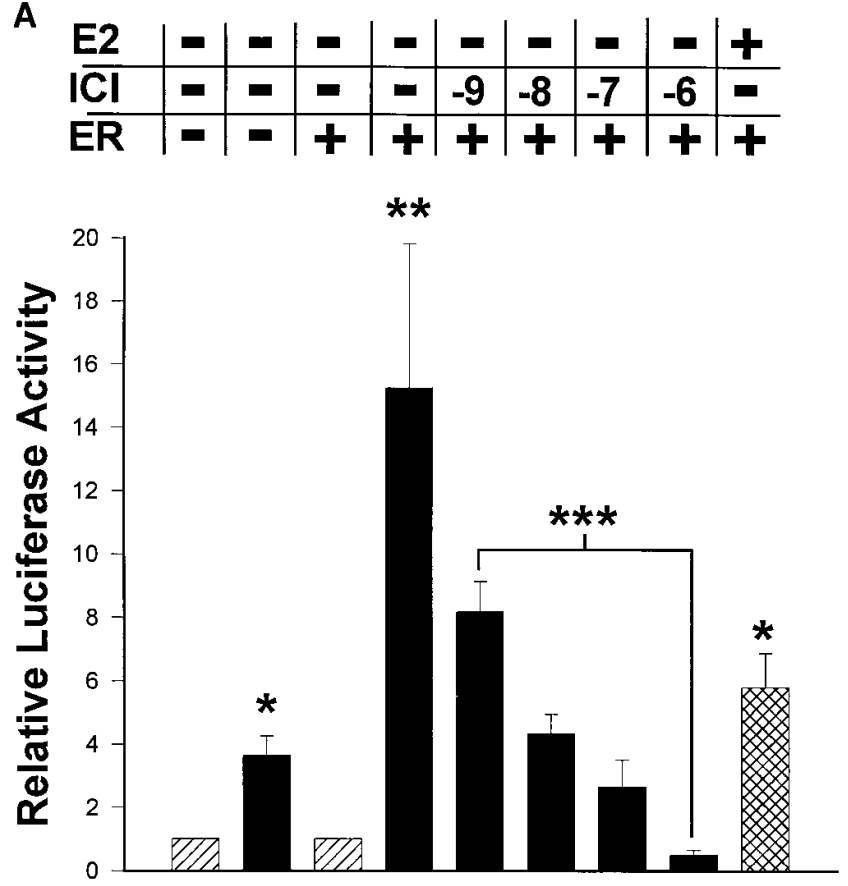

B
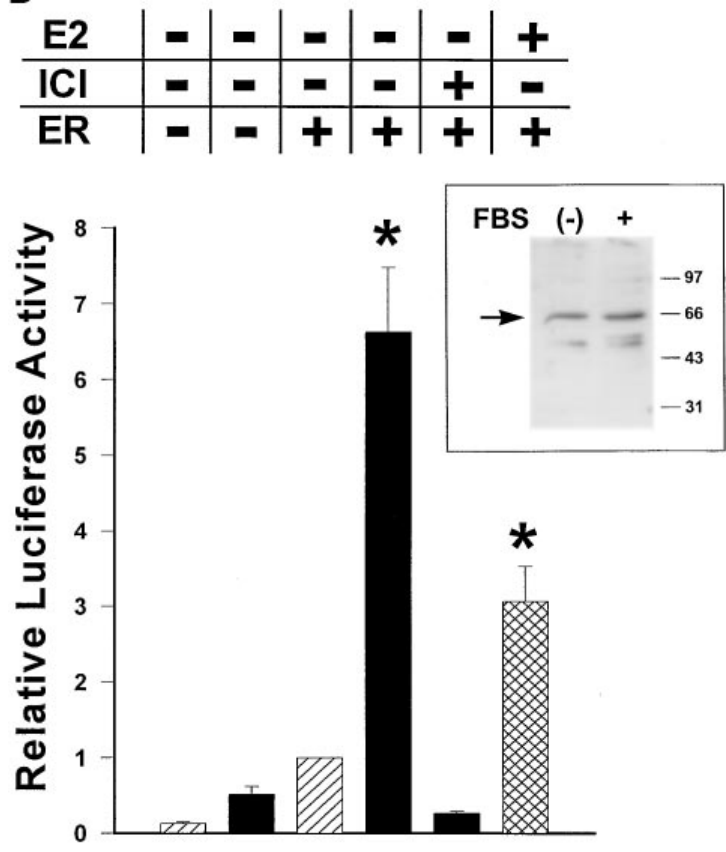

C
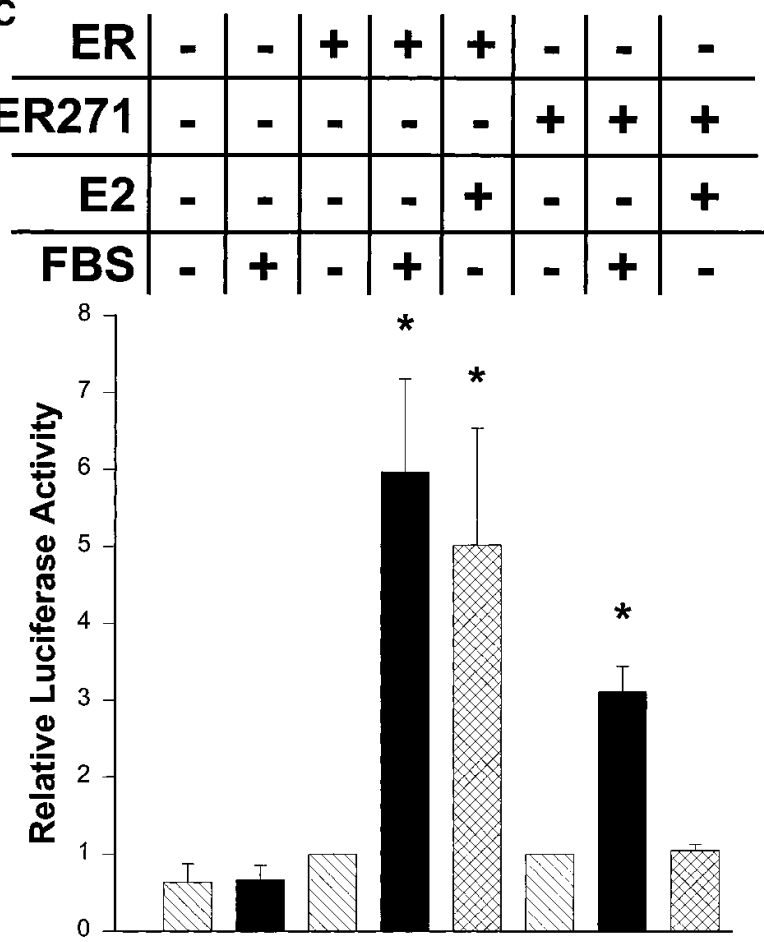

Figure 2. ED-FBS-induced activation of the ERE is mediated by ER. Serum-deprived cells were transfected with the ERE-Luc reporter plasmid along with either a control vector, or an expression plasmid for wild-type ER $(E R)$ or the truncated ER mutant (ER271). Cells were then grown for $48 \mathrm{~h}$ in SFM (hatched bars) without or with (double-hatched bar) $10^{-6} \mathrm{M}$ $\mathrm{E} 2$, or in the presence of $10 \%$ ED-FBS (solid bars) without or with addition of the ER antagonist ICI $182780($ ICI; $\log M)$. (A) In human VSMC, ER overexpression increased ED-FBS-induced transactivation of the ERE reporter and this activation was blocked in a dose-dependent manner by ICI. (B) In PVEC, ED-FBS transactivated the ERE only when the ER was coexpressed. ED-FBS-mediated activation was again blocked by ICI $\left(10^{-6} \mathrm{M}\right)$. (Inset) Immunoblot for ER demonstrates no significant effect of ED-FBS stimulation on ER protein abundance in PVEC treated as in $B$. In untransfected cells, no ER was detectable by Western blot (data not shown; one of three similar experiments is shown). (C) In PVEC, ER271 is activated by ED-FBS, as is the wild-type ER $\alpha$. Note that unlike the wild-type receptor, the truncated form is not $\mathrm{E} 2$ responsive. Bars, mean $( \pm \mathrm{SEM})$ of luciferase activity relative to the activity in quiescent cells. $* P<0.05$ vs. SFM; $* * P<0.05$ vs. SFM and $P<0.05$ vs. ED-FBS treated ER $(-)$ cells; *** $P<0.05$ for trend.

Differential effects of anti-estrogens on ED-FBS-mediated activation of the ER. Anti-estrogens have been categorized into subtypes based largely on differences in their ability to alter activation of AF-1 and AF-2, the two transcriptional activation domains of ER $\alpha$ (63-65). We therefore compared the ability of two anti-estrogens, ICI 182780 (a complete antagonist) and tamoxifen (a mixed agonist/antagonist), to inhibit ED-FBS-induced activation of ER $\alpha$. As Fig. $4 A$ shows, ICI 182780 inhibited ED-FBS-mediated activation of the ERE reporter by $90 \pm 2 \%$ in HSVSMC $(n=15 ; P<0.001)$. In con- trast, tamoxifen acted as a weak agonist at lower doses, and no inhibitory effect was observed at any dose tested. Similar results were found in $\mathrm{HeLa}$ cells cotransfected with pCMV $\mathrm{PCR}_{3}$. In these cells, ICI 182780 inhibited ED-FBS-induced ERELuc activation $87 \pm 2 \%(n=9 ; P<0.01)$ and VEGF- $L u c$ activation $(62 \pm 3 \% ; n=15 ; P<0.05)$, whereas tamoxifen had no significant effect, even at doses up to $1 \mu \mathrm{M}$ (Fig. $4 B$ ).

Effects of specific growth factors on ER activation. To investigate whether stimulation of vascular cells with specific mitogens activates the ER, the effects of EGF and PDGF on cell 
A
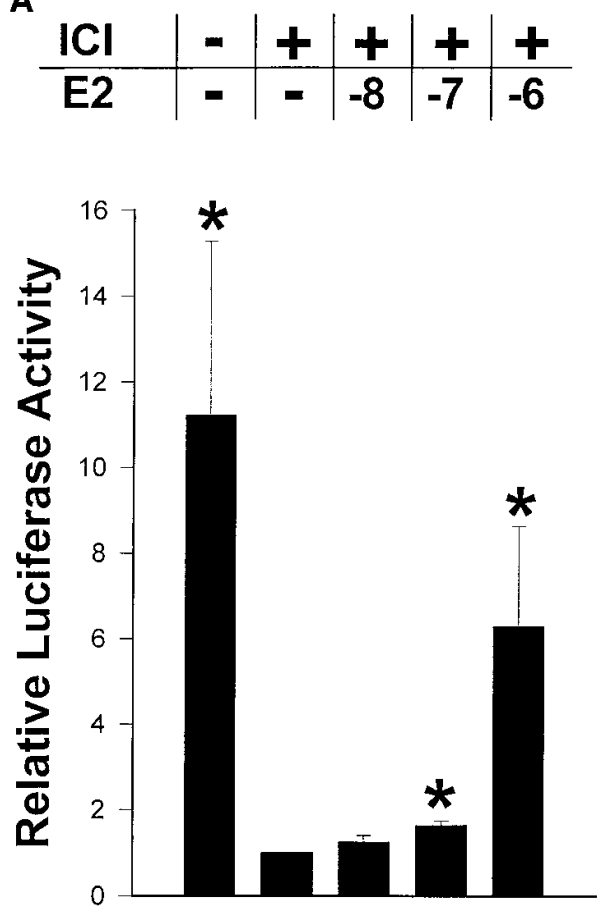

B
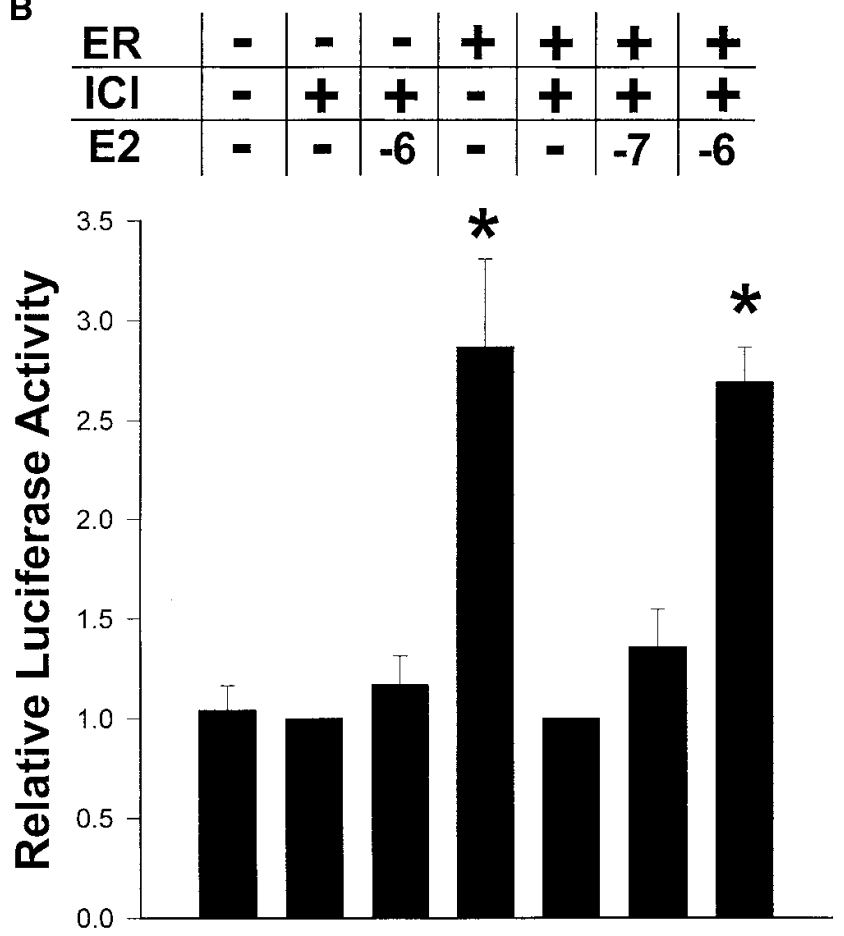

Figure 3. The estrogen receptor mediates ED-FBS-induced activation of VEGF gene expression. VSMC $(A)$ were transfected with the reporter plasmid $m V E G F-L u c$ and maintained in $10 \%$ ED-FBS in the absence or presence of either the ER antagonist ICI 182780 (ICI; $10^{-6} \mathrm{M}$ ) or $17 \beta_{-}$ estradiol (E2). HeLa cells $(B)$ were transiently transfected with the $m V E G F-L u c$ reporter plasmid with or without cotransfection of the pCMV ${ }^{-}$ ER expression plasmid (ER) and maintained in $10 \%$ ED-FBS in the absence or presence of ICI $\left(10^{-6} \mathrm{M}\right)$, with or without addition of E2. Bars, mean $( \pm$ SEM $)$ of luciferase activity relative to the activity in ICI-treated cells. $* P<0.05$ vs. ICI.

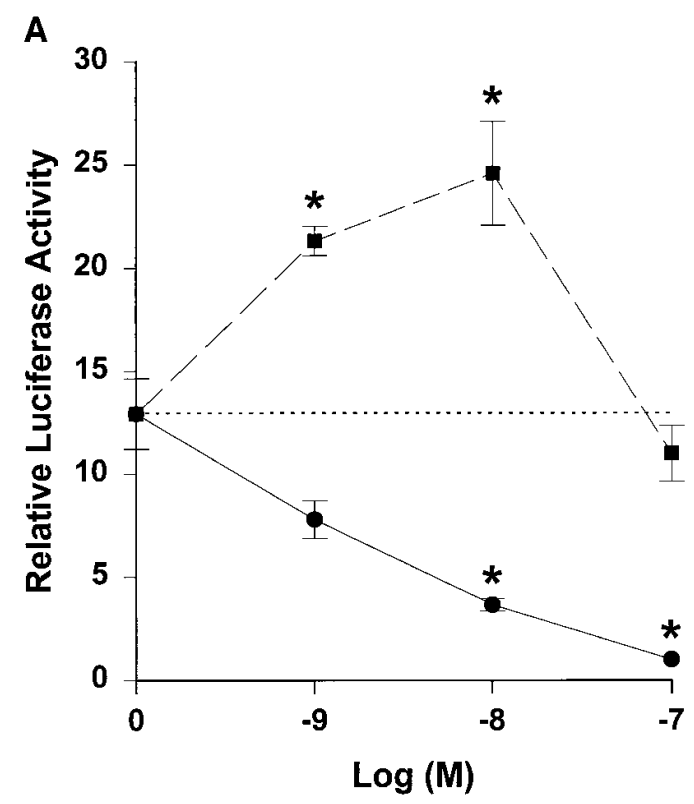

\section{$\mathbf{B}$}
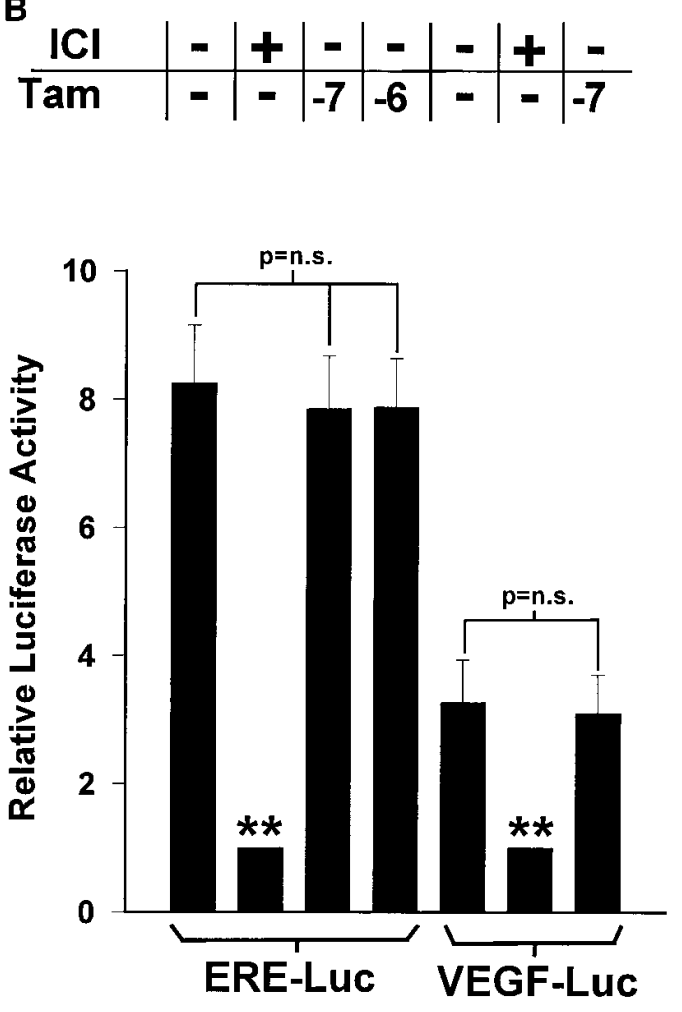

Figure 4. ED-FBS-mediated activation of the ER is blocked by ICI 182780 , but not by tamoxifen. $(A)$ Human VSMC transfected with the ERE-Luc reporter plasmid were treated with $10 \%$ ED-FBS in the presence or absence of ICI 182780 (circles) or tamoxifen (boxes). (B) HeLa cells transfected with the $\mathrm{pCMV}_{3^{-}}$ ER expression plasmid, and either the ERE- $L u c$ or mVEGF-Luc reporter plasmids, and treated with $10 \%$ ED-FBS in the presence or absence of ICI or tamoxifen. Bars, mean $( \pm$ SEM) of luciferase activity relative to the activity in ICI-treated cells. $* P<0.05$ vs. ED-FBS alone; $* * P<0.01$ vs. ED-FBS alone. 
A

B
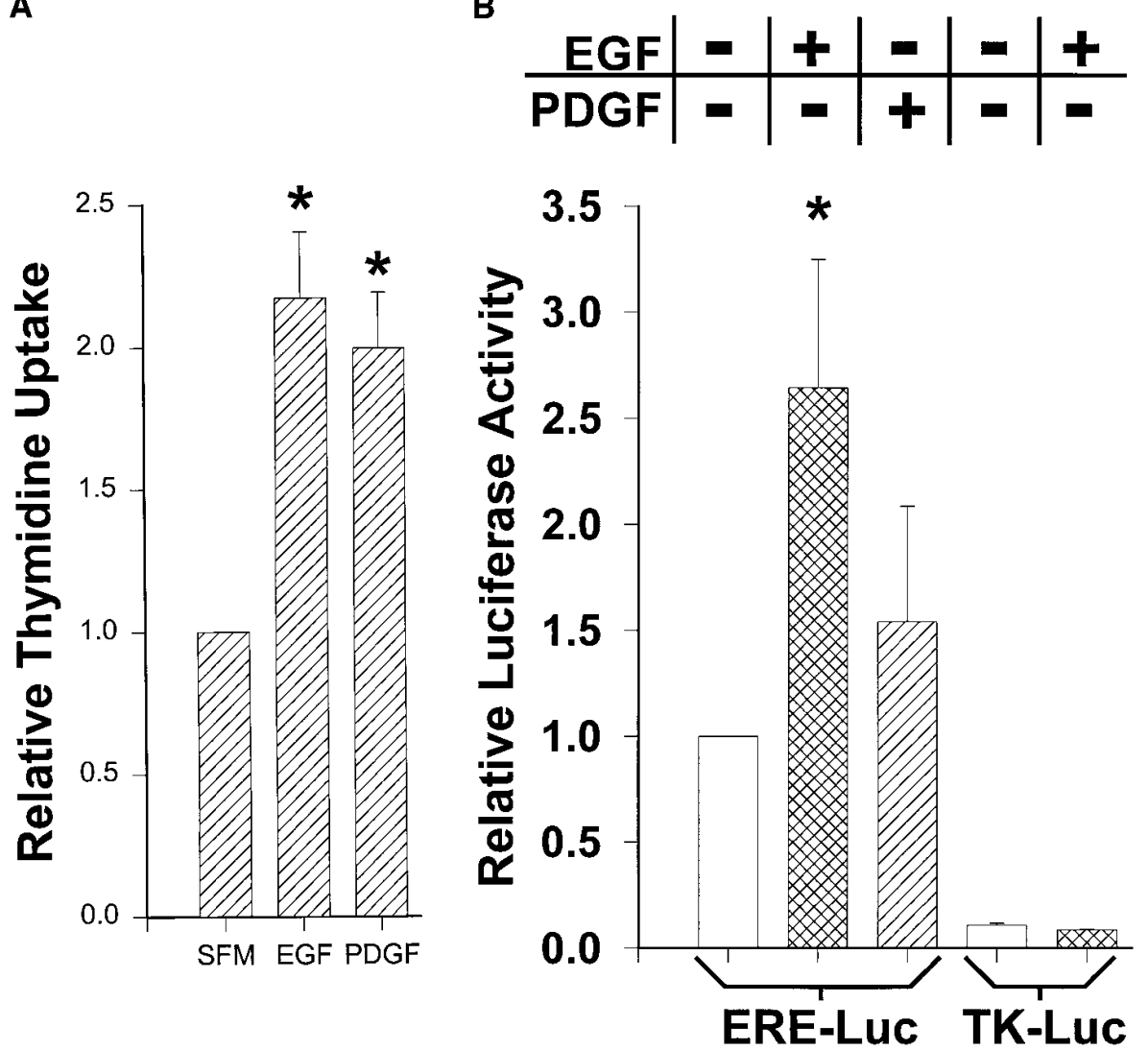
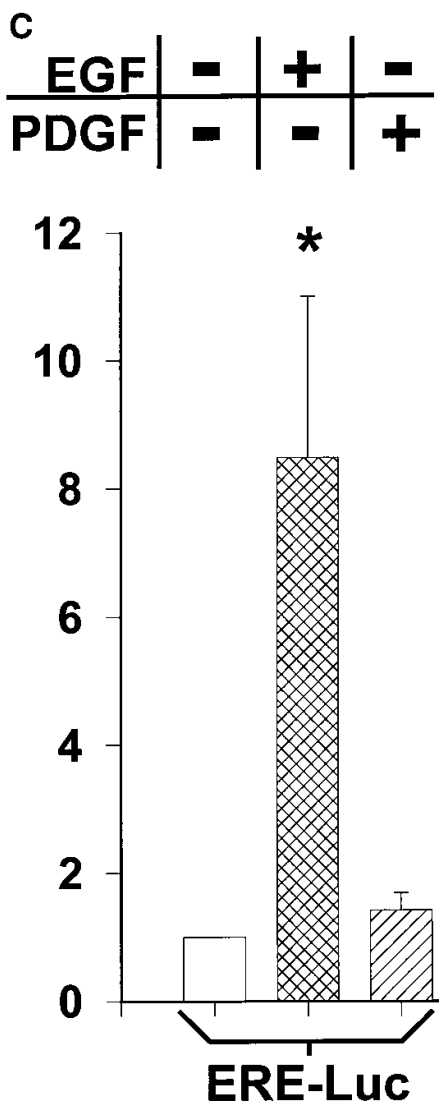

Figure 5. Differential effects of mitogenic stimulation on ER activation in vascular cells. (A) Quiescent VSMC were stimulated with $100 \mathrm{mg} / \mathrm{ml}$ EGF or $10 \mathrm{nM}$ PDGF in the presence of $\left[{ }^{3} \mathrm{H}\right]$ thymidine. Cells were harvested after $24 \mathrm{~h}$ and quantified after the incorporation of $\left[{ }^{3} \mathrm{H}\right]$ thymidine. Both EGF and PDGF treatment increased $\left[{ }^{3} \mathrm{H}\right]$ thymidine uptake $\left(2.2 \pm 0.3\right.$-fold; $n=16 ;{ }^{*} P<0.05$, and $2.0 \pm 0.2$-fold, $n=8 ; P<0.05$, respectively). Quiescent PVEC $(B)$ and VSMC $(C)$ were transiently transfected with the ERE- $L u c$ reporter or the control vector TK- $L u c$ and an ER $\alpha$ expression plasmid and maintained in SFM or stimulated with $100 \mathrm{ng} / \mathrm{ml}$ EGF or $10 \mathrm{nM}$ PDGF for $48 \mathrm{~h}$. In both vascular cell types, EGF, but not PDGF stimulation, significantly increased ERE transactivation but had no effect on the TK-Luc control. Bars, mean ( \pm SEM) of luciferase activity relative to the activity in quiescent cells. ${ }^{*} P<0.01$ vs. SFM.

proliferation and ERE-Luc reporter activity were studied. Stimulation of HSVSMC by EGF or PDGF resulted in a mitogenic response (assessed by incorporation of $\left[{ }^{3} \mathrm{H}\right]$ thymidine; Fig. $5 \mathrm{~A}$ ). EGF stimulation was accompanied by an $8.5 \pm 2.5-$ fold increase in ERE-Luc activity in $\operatorname{HSVSMC~}(n=9 ; P<$ 0.01; Fig. $5 B$ ) and a 2.6 \pm 0.6 -fold increase in ERE-Luc activity in PVEC $(n=24 ; P<0.01$; Fig. $5 B)$. However, in contrast to the effects of EGF, PDGF had no significant effect on ERE activity in either cell type.

$M A P$ kinase inhibition does not alter EGF-mediated ER activation in vascular cells. In nonvascular cells like Cos 1 and $\mathrm{HeL}$, ligand-independent activation of the ER occurs via the MAP kinase pathway $(54,55)$. We therefore examined the effect of the specific MAPKK inhibitor PD98059 on EGF-mediated ER activation in PVEC. Neither 20 nor $60 \mu \mathrm{M}$ PD98059 interfered with EGF-mediated activation of $\mathrm{ER} \alpha$ in PVEC (Fig. 6 A), suggesting ER activation in these vascular cells proceeds via a MAP kinase independent-pathway. Immunoblot analysis of protein lysates from PVEC demonstrated that these concentrations of PD98059 fully inhibited EGF-mediated activation of MAPK (Fig. 6 A, inset).

Hormone-independent activation of the ER in vascular cells does not depend on serine 118. In Cos 1 and HeLa cells, phos- phorylation of serine 118 of the ER is critical for ER activation by MAP kinase $(54,55)$. We therefore investigated the role of serine 118 in mitogenic stimulation of ER activation in vascular cells. A mutant ER, in which an alanine replaces the serine normally found at position 118 (ERs118a) was studied in PVEC, stimulated either with ED-FBS or EGF. ED-FBS treatment resulted in a $5.9 \pm 1.2$-fold increase in activation of the wild-type ER in PVEC $(n=21 ; P<0.01$ vs. SFM; Fig. $6 B)$ and, in contrast to nonvascular cells, a $4.2 \pm 0.7$-fold activation of the mutant ERs118a ( $n=15 ; P=$ n.s. vs. wild type ER). EGF treatment also induced activation of both the wild-type receptor (2.3 \pm 0.5 -fold; $n=30 ; P<0.01$ vs. SFM) and ERs118a to comparable levels $(2.1 \pm 0.5$-fold; $n=30 ; P=$ n.s. vs. wild-type ER; Fig. $6 B$ ). Results were similar in parallel experiments in VSMC (data not shown).

MAPKK activates ER in Cos1 cells, but inhibits ER activation in vascular cells. To investigate further the effect of MAP kinase activation on the ER, we cotransfected constitutively active MAPKK into $\operatorname{Cos} 1$ cells and vascular cells. As previously reported (55), in $\operatorname{Cos} 1$ cells, cotransfection of activated MAPKK resulted in a dose-dependent increase in transcriptional activity of the wild-type ER (maximal activation = 12.0 \pm 2.5 -fold; $n=20 ; P<0.01$; Fig. $7 A$ ), but not the s118a 

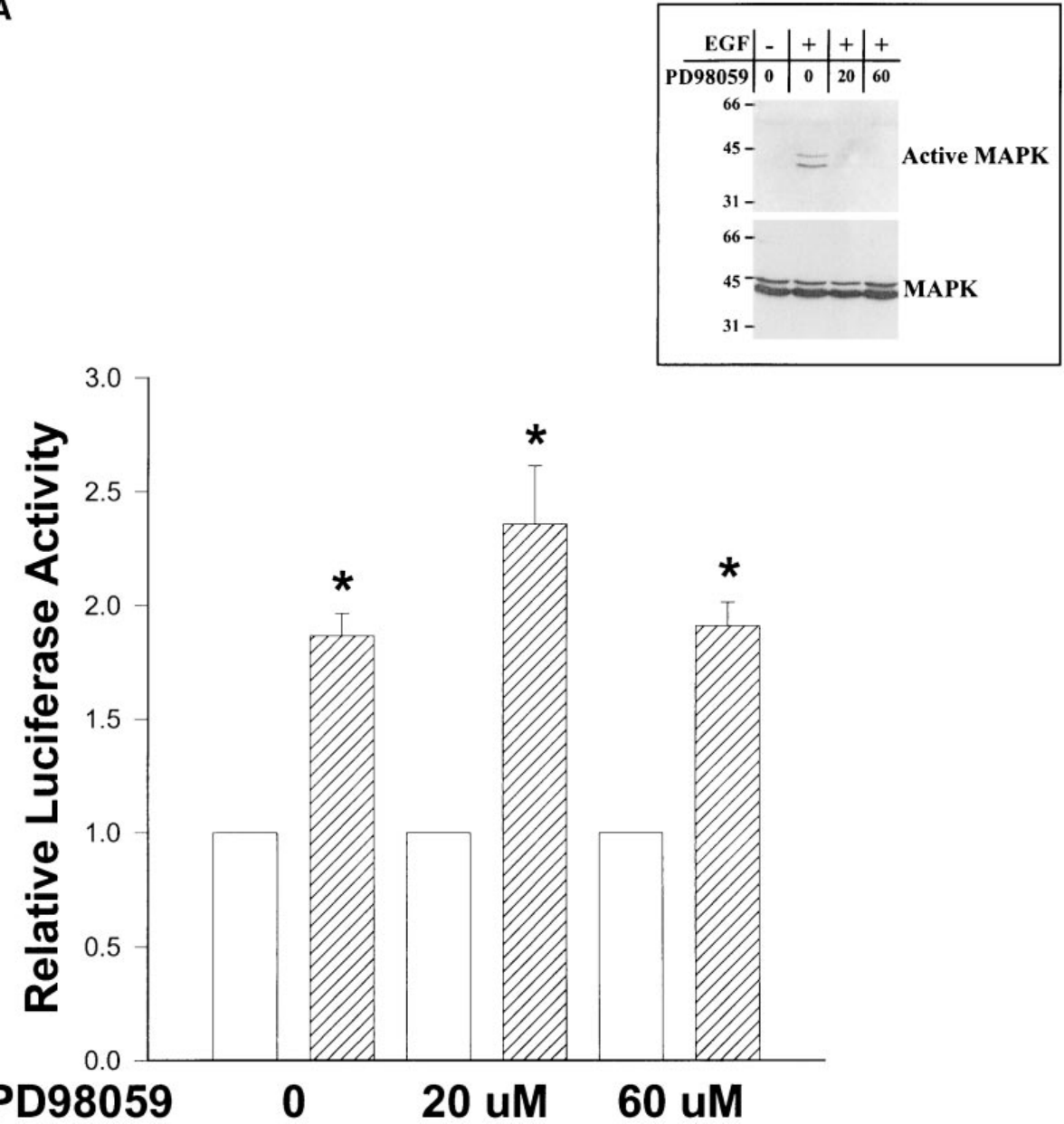

\begin{tabular}{l|l|l|l|l|l|l} 
B ER-WT & + & - & + & - & + & - \\
\hline ER-118a & - & + & - & + & - & +
\end{tabular}

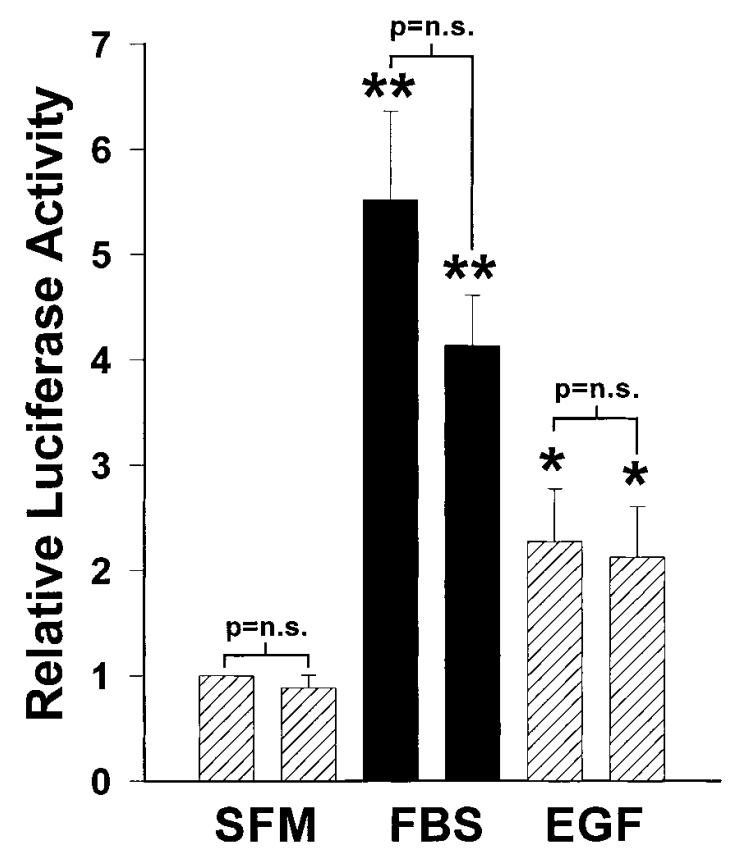

Figure 6. MAP kinase inhibitor does not block ligand-independent ER activation and ED-FBS and EGF activate the wild-type ER and the s118a mutant ER similarly in vascular cells. $(A)$ Quiescent PVEC were maintained in the absence (open bars) or presence of $100 \mathrm{mg} / \mathrm{ml} \mathrm{EGF}$ (hatched bars) with 20 or $60 \mu \mathrm{M}$ of the MAPKK inhibitor PD98059. PD98059 had no effect on the magnitude of EGF-induced ER activation. Bars, mean ( \pm SEM) luciferase activity relative to cells maintained without EGF ( $n=16-48$ each bar; $* P<0.01$ vs. EGF). (Inset) Quiescent PVEC were treated with $100 \mathrm{ng} / \mathrm{ml}$ EGF for 15 min either with or without pretreatment with 20 or $60 \mu \mathrm{M}$ PD98059, and protein lysates were immunoblotted for either active MAPK or total MAPK. PD98059 effectively inhibited EGF-induced MAPK activation. (B) PVEC were transfected with the ERE reporter plasmid and either wild-type $\mathrm{pCMV}_{3}$-ER (ER-WT) or the serine 118-to-alanine mutant ER (ERs118a), and maintained in SFM (hatched bars), 10\% ED-FBS (solid bars), or SFM supplemented with EGF (EGF; $100 \mathrm{ng} / \mathrm{ml})$. ED-FBSand EGF-mediated activation of the ERE both were significant, but did not differ between the wild-type and the s118a receptors for either agonist. Bars, mean $( \pm$ SEM) of luciferase activity relative to the activity in the wild-type transfected quiescent cells. ${ }^{*} P<0.05$ vs. SFM; $* * P<0.01$ vs. SFM. 
A
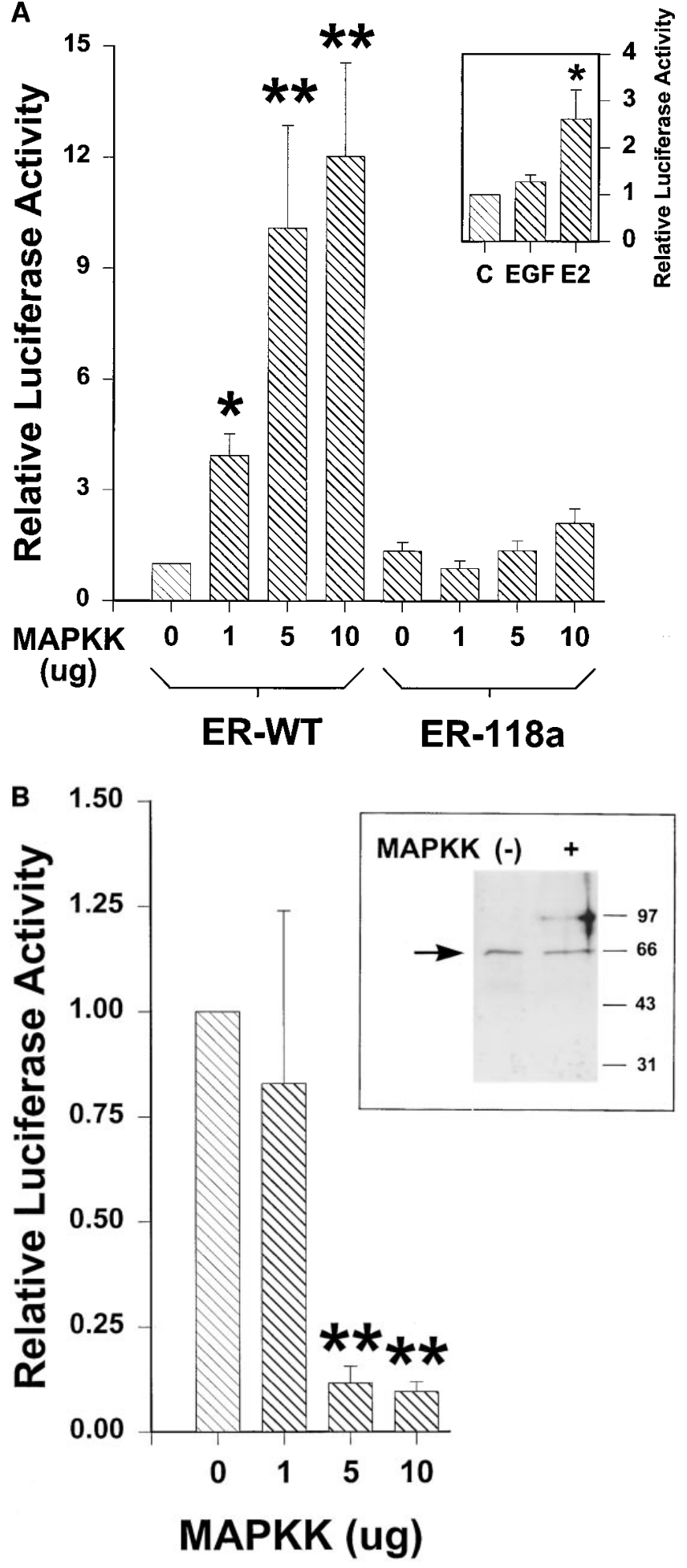

Figure 7. Coexpression of activated MAPK activates the wild-type ER in $\operatorname{Cos} 1$ cells, but inhibits ER activation in vascular cells. Cos cells $(A)$ or PVEC $(B)$ transfected with either $\mathrm{pCMV}_{3}$-ER or $\mathrm{pCMV}_{3^{-}}$ ERs118a and the ERE- $L u c$ reporter plasmid and increasing amounts of constitutively active MAPKK expression plasmid in serum free medium. MAPKK expression resulted in a dose-dependent activation of the wild-type ER in $\operatorname{Cos} 1$ cells, but had no effect on the s118a mutant $(A)$. The s118a mutant ER also was not activated by EGF in Cos 1 cells, but remained responsive to E2 (inset). In PVEC, in contrast to $\operatorname{Cos} 1$ cells, overexpression of MAPKK inhibited ER activation $(B)$. Bars, mean ( \pm SEM) of luciferase activity relative to the ac- mutant (Fig. $7 A$ ). Also as expected, ER-s118a in $\operatorname{Cos} 1$ cells responds to E2, but is not activated by EGF (Fig. $7 A$, inset; $2.6 \pm$ 0.6 -fold activation; $P<0.05$ ). However, cotransfection of the MAPKK expression plasmid in PVEC somewhat surprisingly resulted in a dose-dependent decrease in $\mathrm{ER} \alpha$ activation (maximal level of inhibition $=90 \pm 2 \% ; n=12 ; P<0.01 ;$ Fig. 7 $B)$. The level of $\mathrm{ER} \alpha$ protein was unchanged by cotransfection of MAPKK in PVEC (Fig. 7 , inset), and overexpression of $\mathrm{ER} \alpha$ had no effect on MAP kinase activation as determined by immunoblotting (data not shown). Furthermore, the inhibitory effect of MAPKK expression in PVEC did not result from toxicity to the transfected cells as assessed by trypan blue and $\beta$-galactosidase activity studies (data not shown).

\section{Discussion}

This study demonstrates estrogen-independent activation of the estrogen receptor in vascular cells and shows further that this pathway in vascular cells is independent of MAP kinase and thus distinct from that observed in nonvascular cells. The role of ER $\alpha$ in mediating ED-FBS-induced ERE activation in vascular cells is supported by several observations including: (i) augmentation of the ED-FBS effect in VSMC by cotransfection of an ER expression plasmid; (ii) inhibition of EDFBS-induced activation by ICI 182780; and (iii) the requirement for cotransfection of an ER $\alpha$ expression plasmid for the ED-FBS effect in ER null cells (PVEC and HeLa). Although it is possible that the defined FBS used in the majority of these studies contains very small amounts of estrogen, this alone cannot account for our observations, as hormone-independent ER activation is also observed when the cells are stimulated with either EGF in serum-free medium or with charcoalstripped serum. ED-FBS-mediated activation of ER-271, which lacks the hormone-binding domain, also supports the hormone-independent nature of this pathway. We also found that $\mathrm{ER} \alpha$ can mediate serum-induced activation of VEGF gene expression, suggesting that estrogen-independent activation of the ER can regulate expression of a physiologically relevant gene. We chose to study the VEGF gene for several reasons. VEGF, a secretory product of VSMC (66), acts as a highly specific mitogen for endothelial cells $(67,68)$ and has been implicated in the regulation of neovascularization (6971) and reendothelialization after vascular injury $(72,73)$. In addition, VEGF production is induced by mitogenic and other stimuli in VSMC (74-76) and by estrogen in uterine cells (77) and VSMC (78).

EGF-mediated activation of $\mathrm{ER} \alpha$ has been demonstrated previously in nonvascular cells (51-54). This study extends these findings by demonstrating coupling of mitogenic and steroid receptor-mediated signaling pathways in vascular cells. Though ligand-independent activation of $\mathrm{ER} \alpha$ has been previously reported $(48-50,54,55)$, the molecular pathways that mediate these effects are not well understood. Since two previous reports demonstrated MAPK mediates ligand-independent $\mathrm{ER} \alpha$ activation in nonvascular cells $(54,55)$, we hypothesized first that the ED-FBS and EGF-mediated activation of

tivity in cells not transfected with MAPKK. $* P<0.05$ vs. 0 MAPKK; $* * P<0.01$ vs. 0 MAPKK. ( $B$, inset) Immunoblot analysis demonstrating ER protein abundance in PVEC in the absence or presence of the MAPKK plasmid. Cells were treated as in $B$. 
the ER we observe in vascular cells might be due to activation of AF-1 via the MAPK pathway. However, we found that in vascular endothelial and vascular smooth muscle cells: $(i)$ inhibition of MAPK does not block growth factor-induced ER $\alpha$ activation; (ii) the s118a mutant ER is activatable, and (iii) overexpression of MAPKK inhibits ER activation. Several potential mechanisms for the differential effects of MAPK on ER activation in vascular versus nonvascular cells can be envisioned. MAPK substrates may differ between these cell types, such that $\operatorname{Cos} 1$ cells may express ER-associated proteins that act as transcriptional activators (79-87) after MAPK-mediated phosphorylation, whereas vascular cells may express different ratios of receptor-associated proteins or associated proteins that act as transcriptional repressors (88-91) after MAPK activation. Alternatively, MAPKK could activate different isoforms of MAPK in vascular cells recruiting distinct downstream effector proteins. Another potentially important difference between the vascular cells used in these studies and the nonvascular cells in which ER $\alpha$ is activated in response to MAPKK is that the nonvascular cells are either tumor-derived ( $\mathrm{HeLa}$ cells) or transformed with large $\mathrm{T}$ antigen (Cos 1 cells), and thus likely have altered intracellular signaling pathways. Large $\mathrm{T}$ antigen, for example, binds several critical cellular proteins (for example, $\mathrm{Rb}, \mathrm{p} 53$ ) that themselves interact with known $\mathrm{ER} \alpha$-associated proteins such as the transcriptional integrator p300/CBP (92-94). Indeed, we now have firm evidence that overexpression of large $\mathrm{T}$ antigen in VSMC reverses the inhibitory effects of MAP kinase on ER-mediated transactivation, and alters their phenotype to that of $\operatorname{Cos} 1$ cells for this pathway (R.H. Karas, manuscript in preparation).

In summary, we have demonstrated hormone-independent transcriptional activation of the estrogen receptor in vascular cells after stimulation with estrogen-deficient serum or EGF. Although this vascular cell activation pathway involves the AF-1 domain of $E R \alpha$, it does not appear to proceed via activation of the MAPK pathway. These data underscore the cellspecific nature of steroid hormone action, and suggest an alternate estrogen receptor activation pathway in vascular cells that may be relevant in both men and women.

\section{Acknowledgments}

The authors wish to thank Ms. Patricia Nayak and Ms. Christine Robertson for the expert preparation of this manuscript, and the GRASP Digestive Disease Center (National Institute of Diabetes, Digestive and Kidney Diseases; P30 DK-34928) at New England Medical Center for preparation of plasmid DNA. We also appreciate the excellent technical support of Julie Heyl-Rushmer.

This work was supported in part by a National Institutes of Health Clinical Investigator Award (HL-03036) awarded to R.H. Karas and by National Institutes of Health grant R01 (HL-56069) to Michael E. Mendelsohn. M.E. Mendelsohn is an Established Investigator of the American Heart Association.

\section{References}

1. Colditz, G.A., W.C. Willett, M.J. Stampfer, B. Rosner, F.E. Speizer, and C.H. Hennekens. 1987. Menopause and the risk of coronary heart disease in women. N. Engl. J. Med. 316:1105-1110.

2. Stampfer, M.J., G.A. Colditz, W.C. Willett, J.E. Manson, B. Rosner, F.E. Speizer, and C.H. Hennekens. 1991. Postmenopausal estrogen therapy and cardiovascular disease. N. Engl. J. Med. 325:756-762.

3. Bush, T.L., E. Barrett-Connor, L.D. Cowan, M.H. Crigui, R.B. Wallace, C.M. Suchindran, H.A. Tyroler, and B.M. Rifkind. 1987. Cardiovascular mor- tality and noncontraceptive use of estrogen in women: results from the lipid research clinics program follow-up study. Circulation. 75:1102-1109.

4. Grady, D., S.M. Rubin, D.B. Petitti, C.S. Fox, D. Black, B. Ettinger, V.L. Ernster, and S.R. Cummings. 1992. Hormone therapy to prevent disease and prolong life in postmenopausal women. Ann. Intern. Med. 117:1016-1037.

5. Writing Group for the PEPI Trial. 1995. Effects of estrogen or estrogen/ progestin regimens on heart disease risk factors in postmenopausal women: the Postmenopausal Estrogen/Progestin Interventions (PEPI) Trial. JAMA (J. Am. Med. Assoc.) 273:199-208.

6. Nabulsi, A.A., A.R. Folsom, A. White, W. Patsch, G. Geiss, K.K. Wu, and M. Szklo. 1993. Association of hormone-replacement therapy with various cardiovascular risk factors in postmenopausal women. N. Engl. J. Med. 328: 1069-1075.

7. Gebara, O.C.E., M.A. Mittleman, P. Sutherland, I. Lipinska, T. Matheney, P. Xu, F.K. Welty, P.W.F. Wilson, D. Levy, J.E. Muller, and G.H. Tofler. 1995. Association between increased estrogen status and increased fibrinolytic potential in the Framingham Offspring Study. Circulation. 91:1952-1958.

8. Mendelsohn, M.E., and R.H. Karas. 1994. Estrogen and the blood vessel wall. Curr. Op. Cardiol. 9:619-626.

9. Williams, J.K., M.R. Adams, and H.S. Klopfenstein. 1990. Estrogen modulates responses of atherosclerotic coronary arteries. Circulation. 81:1680-1687.

10. Williams, J.K., M.R. Adams, D.M. Herrington, and T.B. Clarkson. 1992. Short-term administration of estrogen and vascular responses of atherosclerotic coronary arteries. J. Am. Coll. Cardiol. 20:452-457.

11. Reis, S.E., S.T. Gloth, R.S. Blumenthal, J.R. Resar, H.A. Zacur, G. Gerstenblith, and J.A. Brinker. 1994. Ethinyl estradiol acutely attenuates abnormal coronary vasomotor responses to acetylcholine in postmenopausal women. Circulation. 89:52-60.

12. Zhang, F., J.L. Ram, P.R. Standley, and J.R. Sowers. 1994. 17ß-Estradiol attenuates voltage-dependent $\mathrm{Ca}^{2+}$ currents in A7r5 vascular smooth muscle cell line. Am. J. Physiol. (Cell Physiol.) 266:C975-C980.

13. Chang, W.C., J. Nakao, H. Orimo, and S.I. Murota. 1980. Stimulation of prostaglandin cyclooxygenase and prostacyclin synthetase activities by estradiol in rat aortic smooth muscle cells. Biochim. Biophys. Acta. 620:472-482.

14. Jiang, C., P.M. Sarrel, P.A. Poole-Wilson, and P. Collins. 1992. Acute effect of $17 \beta$-estradiol on rabbit coronary artery contractile responses to endothelin-1. Am. J. Physiol. 263:H271-H275.

15. Collins, P., J. Shay, C. Jiang, and J. Moss. 1994. Nitric oxide accounts for dose-dependent estrogen-mediated coronary relaxation after acute estrogen withdrawal. Circulation. 90:1964-1968.

16. Redmond, E.M., M.N. Cherian, and R.C. Wetzel. 1994. 17ß-Estradiol inhibits flow- and acute hypoxia-induced prostacyclin release from perfused endocardial endothelial cells. Circulation. 90:2519-2524.

17. Koike, H., R.H. Karas, W. Baur, T.F. O’Donnell, Jr., and M.E. Mendelsohn. 1996. Differential display PCR identifies nucleophosmin as an estrogenregulated gene in human vascular smooth muscle cells. J. Vasc. Surg. 23:477-482.

18. Orimo, A., S. Inoue, A. Ikegami, T. Hosoi, M. Akishita, Y. Ouchi, M. Muramatsu, and H. Orimo. 1993. Vascular smooth muscle cells as target for estrogen. Biochem. Biophys. Res. Commun. 195:730-736.

19. Jiang, C., P.M. Sarrel, D.C. Lindsey, P.A. Poole-Wilson, and P. Collins. 1991. Endothelium-independent relaxation of rabbit coronary artery by $17 \beta-$ oestradiol in vitro. Br. J. Pharmacol. 104:1033-1037.

20. White, R.E., D.J. Darkow, and J.L.F. Lang. 1995. Estrogen relaxes coronary arteries by opening $\mathrm{BK}_{\mathrm{Ca}}$ channels through a cGMP-dependent mechanism. Circ. Res. 77:936-942.

21. Weiner, C.P., I. Lizasoain, S.A. Baylis, R.G. Knowles, I.G. Charles, and $\mathrm{S}$. Moncada. 1994. Induction of calcium-dependent nitric oxide synthases by sex hormones. Proc. Natl. Acad. Sci. USA. 91:5212-5216.

22. Bhalla, R.C., K.F. Toth, R.A. Bhatty, L.P. Thompson, and R.V. Sharma 1997. Estrogen reduces proliferation and agonist-induced calcium increase in coronary artery smooth muscle cells. Am. J. Physiol. 272:H1996-H2003.

23. Fischer-Dzoga, K., R. Wissler, and D. Vesselinovitch. 1983. The effect of estradiol on the proliferation of rabbit aortic medial tissue cells induced by hyperlipemic serum. Exp. Mol. Pathol. 39:355-363.

24. Vargas, R., B. Wroblewska, A. Rego, J. Hatch, and P.W. Ramwell. 1993. Oestradiol inhibits smooth muscle cell proliferation of pig coronary artery. $\mathrm{Br}$. J. Pharmacol. 109:612-617.

25. Kolodgie, F.D., A. Jacob, P.S. Wilson, G.C. Carlson, A. Farb, A Verma, and R. Virmani. 1996. Estradiol attenuates directed migration of vascular smooth muscle cells in vitro. Am. J. Pathol. 148:969-976.

26. Morales, D.E., K.A. McGowan, D.S. Grant, S. Maheshwari, D Bhartiya, M.C. Cid, H.K. Kleinman, and W. Schnaper. 1995. Estrogen promotes angiogenic activity in human umbilical vein endothelial cells in vitro and in a murine model. Circulation. 91:755-763.

27. Losordo, D.W., M. Kearney, E.A. Kim, J. Jekanowski, and J.M. Isner. 1994. Variable expression of the estrogen receptor in normal and atherosclerotic coronary arteries of premenopausal women. Circulation. 89:1501-1510.

28. Karas, R.H., B.L. Patterson, and M.E. Mendelsohn. 1994. Human vascular smooth muscle cells contain functional estrogen receptor. Circulation. 89: 1943-1950.

29. Kim-Schulze, S., K.A. McGowan, S.C. Hubchak, M.C. Cid, M.B. Martin, H.K. Kleinman, G.L. Greene, and H.W. Schnaper. 1996. Expression of an 
estrogen receptor by human coronary artery and umbilical vein endothelial cells. Circulation. 94:1402-1407.

30. Venkov, C.D., A.B. Rankin, and D.E. Vaughan. 1996. Identification of authentic estrogen receptor in cultured endothelial cells: a potential mechanism for steroid hormone regulation of endothelial function. Circulation. 94:727-733.

31. Caulin-Glaser, T., G.A. Watson, R. Pardi, and J.R. Bender. 1996. Effects of $17 \beta$-estradiol on cytokine-induced endothelial cell adhesion molecular expression. J. Clin. Invest. 98:36-42.

32. Lantin-Hermoso, R.L., C.R. Rosenfeld, I.S. Yuhanna, Z. German, Z. Chen, and P.W. Shaul. 1997. Estrogen acutely stimulates nitric oxide synthase activity in fetal pulmonary artery endothelium. Am. J. Physiol. (Lung Cell. Mol. Physiol.) 273:L119-L126.

33. Caulin-Glaser, T., G. García-Cardeña, P. Sarrel, W.C. Sessa, and J.R. Bender. 1997. 17 $\beta$-Estradiol regulation of human endothelial cell basal nitric oxide release, independent of cytosolic $\mathrm{Ca}^{2+}$ mobilization. Circ. Res. 81:885-892.

34. Gishel, N., K.L. Timmins, S.J. Duffy, T.T. Binh, R.C. O’Brien, R.W. Harper, and I.T. Meredith. 1997. Long-term estrogen therapy improves vascular function in male to female transsexuals. Am. Coll. Cardiol. 29:1437-1444.

35. McCrohon, J.A., W.A.W. Walters, J.T.C. Robinson, R.J. McCredie, L. Turner, M.R. Adams, D.J. Handelsman, and D.S. Celermajer. 1997. Arterial reactivity is enhanced in genetic males taking high dose estrogens. Am. Coll. Cardiol. 29:1432-1436.

36. Blumenthal, R.S., A.W. Heldman, J.A. Brinker, J.R. Resar, V.J. Coombs, S.T. Gloth, and G. Gerstenblith. 1997. Acute effects of conjugated estrogens on coronary blood flow response to acetylcholine in men. Am. J. Cardiol. 80:1021-1024.

37. Chen, S.J., H.B. Li, J. Durand, S. Oparil, and Y.F. Chen. 1996. Estrogen reduces myointimal proliferation after balloon injury of rat carotid artery. Circulation. 93:577-584.

38. Bourassa, P.A.K., P.M. Milos, B.J. Gaynor, J.L. Breslow, and R.J. Aiello. 1996. Estrogen reduces atherosclerotic lesion development in apolipoprotein E-deficient mice. Proc. Natl. Acad. Sci. USA. 93:10022-10027.

39. Eddy, E.M., T.F. Washburn, D.O. Bunch, E.H. Goulding, B.C. Gladen, D.B. Lubahn, and K.S. Korach. 1996. Targeted disruption of the estrogen receptor gene in male mice causes alteration of spermatogenesis and infertility. Endocrinology. 137:4796-4805.

40. Ogawa, S., D.B. Lubahn, S.K. Korach, and D.W. Pfaff. 1997. Behavioral effects of estrogen receptor gene disruption in male mice. Proc. Natl. Acad. Sci. USA. 94:1476-1481.

41. Lubahn, D.B., J.S. Moyer, T.S. Golding, J.F Couse, K.S. Korach, and O. Smithies. 1993. Alteration of reproductive function but not prenatal sexual development after insertional disruption of the mouse estrogen receptor gene. Proc. Natl. Acad. Sci. USA. 90:11162-11166.

42. Hess, R.A., D. Bunick, K.-H. Lee, J. Bahr, J.A. Taylor, K.S. Korach, and D.B. Lubahn. 1997. A role for oestrogens in the male reproductive system. Nature. 390:509-512.

43. Sudhir, K., T.M. Chou, L.M. Messina, S.J. Hutchison, K.S. Korach, K. Chatterjee, and G. M. Rubanyi. 1997. Endothelial dysfunction in a man with disruptive mutation in oestrogen-receptor gene. Lancet. 349:1146-1147.

44. Smith, E.P., J. Boyd, G.R. Frank, H. Takahashi, R.M. Cohen, B. Specker, T.C. Williams, D.B. Lubahn, and K.S. Korach. 1994. Estrogen resistance caused by a mutation in the estrogen-receptor gene in a man. N. Engl. J. Med. 331:1056-1061.

45. Evans, R.M. 1988. The steroid and thyroid hormone receptor superfamily. Science. 240:889-895.

46. King, R.J.B. 1987. Structure and function of steroid receptors. J. Endocrinol. 114:341-349.

47. Power, R.F., S.K. Mani, J. Codina, O.M. Conneely, and B.W. O'Malley. 1991. Dopaminergic and ligand-dependent activation of steroid hormone receptors. Science. 254:1636-1639.

48. El-Tanani, M.K.K., and C.D. Green. 1997. Two separate mechanisms for ligand-independent activation of the estrogen receptor. Mol. Endocrinol. 11:928-937.

49. Zwijsen, R.M.L., E. Wientjens, R. Klompmaker, J. Van der Sman, R. Bernards, and R.J.A.M. Michalides. 1997. CDK-independent activation of estrogen receptor by cyclin D1. Cell. 88:405-415.

50. Trowbridge, J.M., I. Rogatsky, and M.J. Garabedian. 1997. Regulation of estrogen receptor transcriptional enhancement by the cyclin A Cdk2 complex. Proc. Natl. Acad. Sci. USA. 94:10132-10137.

51. Ignar-Trowbridge, D.M., C.T. Teng, K.A. Ross, M.G. Parker, K.S. Korach, and J.A. McLachlan. 1993. Peptide growth factors elicit estrogen receptor-dependent transcriptional activation of an estrogen-responsive element. Mol. Endocrinol. 7:992-998.

52. Ignar-Trowbridge, D.M., K.G. Nelson, M.C. Bidwell, S.W. Curtis, T.F. Washburn, J.A. McLachlan, and K.S. Korach. 1992. Coupling of dual signaling pathways: epidermal growth factor action involves the estrogen receptor. Proc. Natl. Acad. Sci. USA. 89:4658-4662.

53. Ignar-Trowbridge, D.M., C.T. Teng, K.A. Ross, M.G. Parker, K.S. Korach, and J.A. McLachlan. 1993. Peptide growth factors elicit estrogen receptor-dependent transcriptional activation of an estrogen-responsive element. Mol. Endocrinol. 7:992-998.

54. Bunone, G., P.A. Briand, R.J. Miksicek, and D. Picard. 1996. Activation of the unliganded estrogen receptor by EGF involves the MAP kinase pathway and direct phosphorylation. EMBO (Eur. Mol. Biol. Organ.) J. 15:2174-2183.

55. Kato, S., H. Endoh, Y. Masuhiro, T. Kitamoto, S. Uchiyama, H. Sasaki, S. Masushige, Y. Gotoh, E. Nishida, H. Kawashima, D. Metzger, and P. Chambon. 1995. Activation of the estrogen receptor through phosphorylation by mitogen-activated protein kinase. Science. 270:1491-1494.

56. Libby, P., and K.V. O'Brien. 1983. Culture of quiescent arterial smooth muscle cells in a defined serum-free medium. J. Cell. Physiol. 115:217-223.

57. Glass, C.K., J.M. Holloway, O.V. Devary, and M.G. Rosenfeld. 1988 The thyroid hormone receptor binds with opposite transcriptional effects to a common sequence motif in thyroid hormone and estrogen response elements. Cell. 54:313-323.

58. Kunkel, T.A., J.D. Roberts, and R.A. Zakour. 1987. Rapid and efficient site-specific mutagenesis without phenotypic selection. Methods Enzymol. 154:367382.

59. Gotoh, Y., S. Matsuda, K. Takenaka, S. Hattori, A. Iwamatsu, M. Ishikawa, H. Kosako, and E. Nishida. 1994. Characterization of recombinant $X e$ nopus MAP kinase kinases mutated at potential phosphorylation sites. Oncogene. 9:1891-1898.

60. Pumiglia, K.M., and S.J. Decker. 1997. Cell cycle arrest mediated by the MEK/mitogen-activated protein kinase pathway. Proc. Natl. Acad. Sci. USA. 94:1476-1481.

61. Brown, P.J., and A. Schonbrunn. 1993. Affinity purification of a somatostatin receptor-G-protein complex demonstrates specificity in receptor-G-protein coupling. J. Biol. Chem. 268:6668-6676.

62. Green, S., P. Walter, V. Kumar, A. Krust, J.-M. Bornert, P. Argos, and P. Chambon. 1986. Human oestrogen receptor cDNA: sequence, expression and homology to v-erb-A. Nature. 320:134-139.

63. Tzukerman, M.T., A. Esty, D. Santiso-Mere, P. Danielian, M.G. Parker, R.B. Stein, J.W. Pike, and D.P. McDonnell. 1994. Human estrogen receptor transactivational capacity is determined by both cellular and promoter context and mediated by two functionally distinct intramolecular regions. Mol. Endocrinol. 8:21-30.

64. McDonnell, D.P., D.L. Clemm, T. Hermann, M.E. Goldman, and J.W. Pike. 1995. Analysis of estrogen receptor function in vitro reveals three distinct classes of antiestrogens. Mol. Endocrinol. 9:659-669.

65. Metzger, D., M. Berry, S. Ali, and P. Chambon. 1995. Effect of antagonists on DNA binding properties of the human estrogen receptor in vitro and in vivo. Mol. Endocrinol. 9:579-591.

66. Ferrara, N., J. Winer, and T. Burton. 1991. Aortic smooth muscle cells express and secrete vascular endothelial growth factor. Growth Factors. 5:141-148.

67. Fox, J.C., and J.L. Swain. 1996. Angiogenic gene therapy: a leg to stand on? Circulation 94:3065-3066.

68. Majesky, M.W. 1996. A little VEGF goes a long way: Therapeutic angiogenesis by direction of injection of vascular endothelial growth factor-encoding plasmid DNA. Circulation. 94:3062-3064.

69. Tsurumi, Y., S. Takeshita, D. Chen, M. Kearney, S.T. Rossow, J. Passeri, J.R. Horowitz, J.F. Symes, and J.M. Isner. 1996. Direct intramuscular gene transfer of naked DNA encoding vascular endothelial growth factor augments collateral development and tissue perfusion. Circulation. 94:3281-3290.

70. Ferrara, N., K. Carver-Moore, H. Chen, M. Dowd, L. Lu, K.S. O'Shea L. Powell-Braxton, K.J. Hillan, and M.W. Moore. 1996. Heterozygous embry onic lethality induced by targeted inactivation of the VEGF gene. Nature. 380: 439-442.

71. Carmeliet, P., V. Ferreira, G. Breir, S. Pollefeyt, L. Kiechens, M. Gertsenstein, M. Fahrig, A. Vandenhoeck, K. Harpal, C. Eberhardt, C. Declercq, J. Pawling, L. Moons, D. Collen, W. Risau, and A. Nagy. 1996. Abnormal blood vessel development and lethality in embryos lacking a single VEGF allele. $\mathrm{Na}$ ture. 380:435-439.

72. Ashara, T., D. Chen, Y. Tsurumi, M. Kearney, S.T. Rossow, J. Paseri, J.F. Symes, and J.M. Isner. 1996. Accelerated restitution of endothelial integrity and endothelium-dependent function after phVEGF ${ }_{165}$ gene transfer. Circulation. 94:3291-3302.

73. Krasinski, K., I. Spyridopoulos, T. Asahara, R. Van der Zee, J.M. Isner, and D.W. Losordo. 1997. Estradiol accelerates functional endothelial recovery after arterial injury. Circulation. 95:1768-1772.

74. Brogi, E., T. Wu, A. Namiki, and J.M. Isner. 1994. Indirect angiogenic cytokines upregulated VEGF and bFGF gene expression in vascular smooth muscle cells, whereas hypoxia upregulates VEGF expression only. Circulation. 90:649-652.

75. Levy, A.P., N.S. Levy, S. Wegner, and M.A. Goldberg. 1995. Transcriptional regulation of the rat vascular endothelial growth factor gene by hypoxia. J. Biol. Chem. 270:13333-13340.

76. Shweiki, D., A. Itin, D. Soffer, and E. Keshet. 1992. Vascular endothelial growth factor induced by hypoxia may mediate hypoxia-initiated angiogenesis. Nature. 359:843-845.

77. Cullinan-Bove, K., and R.D. Koos. 1993. Vascular endothelial growth factor/vascular permeability factor expression in the rat uterus: rapid stimulation by estrogen correlates with estrogen-induced increases in uterine capillary permeability and growth. Endocrinology. 133:829-837.

78. Karas, R.H., H.E. Bieber, W.E. Baur, and M.E. Mendelsohn. 1996. Estrogen enhances vascular endothelial growth factor (VEGF) gene expression in 
human vascular smooth muscle cells. Circulation. 94:I595.

79. Smith, C.L., S.A. Oñate, M.J. Tsai, and B.W. O'Malley. 1996. CREB binding protein acts synergistically with steroid receptor coactivator-1 to enhance steroid receptor-dependent transcription. Proc. Natl. Acad. Sci. USA. 93: 8884-8888.

80. Hanstein, B., R. Eckner, J. DiRenzo, S. Halachmi, H. Liu, B. Searcy, R. Kurokawa, and M. Brown. 1996. p300 is a component of an estrogen receptor coactivator complex. Proc. Natl. Acad. Sci. USA. 93:11540-11545.

81. Cavaillès, V., S. Cauvois, F. L'Horset, G. Lopez, S. Hoare, P.J. Kushner, and M.G. Parker. 1995. Nuclear factor RIP140 modulates transcriptional activation by the estrogen receptor. EMBO (Eur. Mol. Biol. Organ.) J. 14:37413751.

82. Onate, S.A., S.Y. Tsai, M.J. Tsai, and B.W. O'Malley. 1995. Sequence and characterization of a coactivator for the steroid hormone receptor superfamily. Science. 270:1354-1357.

83. Cavaillès, V., S. Dauvois, P.S. Danielian, and M.G. Parker. 1994. Interaction of proteins with transcriptionally active estrogen receptors. Proc. Natl. Acad. Sci. USA. 91:10009-10013.

84. Hunter, T. 1996. A growing coactivator network. Nature. 383:22-23.

85. Baniahmad, C., Z. Nawaz, A. Baniahmad, M.A.G. Gleeson, M.-J. Tsai, and B.W. O'Malley. 1995. Enhancement of human estrogen receptor activity by SPT6: a potential coactivator. Mol. Endocrinol. 9:34-43.

86. Halachmi, S., E. Marden, G. Martin, H. MacKay, C. Abbondanza, and
M. Brown. 1994. Estrogen receptor-associated proteins: possible mediators of hormone-induced transcription. Science. 264:1455-1458.

87. McInerney, E.M., M.J. Tsai, B.W. O'Malley, and B.S. Katzenellenbogen. 1996. Analysis of estrogen receptor transcriptional enhancement by a nuclear hormone receptor coactivator. Proc. Natl. Acad. Sci. USA. 93:1006910073.

88. Horlein, A.J. 1995. Ligand-dependent repression by the thyroid hormone receptor mediated by a nuclear receptor co-repressor. Nature. 377:397-404

89. Kurokawa, R. 1995. Polarity-specific activities of retinoic acid receptors determined by a co-repressor. Nature. 377:451-454.

90. Chen, J.D., and R.M. Evans. 1995. A transcriptional co-repressor that interacts with nuclear hormone receptors. Nature. 377:454-457.

91. Chen, J.D., and R.M. Evans. 1996. SMRT isoforms mediate repression and anti-repression of nuclear receptor heterodimers. Proc. Natl. Acad. Sci. USA. 93:7567-7571.

92. Chakravarti, D. 1996. Role of CBP/P300 in nuclear receptor signalling. Nature. 383:99-103.

93. Gu, W., X.L. Shi, and R.G. Roeder. 1997. Synergistic activation of transcription by CBP and p53. Nature. 387:819-823.

94. Lill, N.L., S.R. Grossman, D. Ginsberg, J. DeCaprio, and D.M. Livingston. 1997. Binding and modulation of p53 by p300/CBP coactivators. Nature. 387:823-827. 